\title{
Immune-modulating Effect of Korean Red Ginseng by Balancing the Ratio of Peripheral T Lymphocytes in Bile Duct or Pancreatic Cancer Patients With Adjuvant Chemotherapy
}

\author{
IM-KYUNG KIM ${ }^{1}$, KANG YOUNG LEE ${ }^{1}$, JEONGHYUN KANG ${ }^{2}$, JOON SEONG PARK ${ }^{2}$ and JOON JEONG ${ }^{2}$ \\ ${ }^{1}$ Department of Surgery, Severance Hospital, Yonsei University College of Medicine, Seoul, Republic of Korea; \\ ${ }^{2}$ Department of Surgery, Gangnam Severance Hospital, \\ Yonsei University College of Medicine, Seoul, Republic of Korea
}

\begin{abstract}
Background/Aim: We aimed to clarify the clinical effect of Korean Red ginseng administered with adjuvant chemotherapy on the immune function of patients with bile duct or pancreatic cancer. Patients and Methods: This was a prospective, randomized controlled trial conducted at a single tertiary center. Twenty-six consecutive patients who underwent curative resection for bile duct or pancreatic cancer followed by 5-fluorouracil/leucovorin or gemcitabine chemotherapy were included. They were randomized 1:1 to the ginseng and control groups. Immune and inflammatory markers were assayed in peripheral blood samples during and after chemotherapy. Results: Intergroup differences in immune-related parameters before and during chemotherapy were not significant. After chemotherapy, the percentage of $\mathrm{CD}^{+}$T lymphocytes was significantly higher in the ginseng group than in the control group $142.01 \%$ vs. $33.69 \%$, $\mathrm{p}=0.048)$. The ratio of $\mathrm{CD}^{+} / \mathrm{CD} 8^{+} \mathrm{T}$ lymphocytes was also higher in the ginseng group (2.03 vs. 1.28, p=0.027). Neutropenia and liver dysfunction prevalence did not differ between the groups. Conclusion: The ginseng group, which received Korean Red ginseng daily during adjuvant
\end{abstract}

This article is freely accessible online.

Correspondence to: Prof. Joon Seong Park, Department of Surgery, Gangnam Severance Hospital, Yonsei University College of Medicine, 211 Eonju-ro, Gangnam-gu, Seoul, 06273, Republic of Korea. Tel: +82 220193378, Fax: +82 234625994, e-mail: jspark330@yuhs.ac; Prof. Joon Jeong, Department of Surgery, Gangnam Severance Hospital, Yonsei University College of Medicine, 211 Eonju-ro, Gangnam-gu, Seoul, 06273, Republic of Korea. Tel: +82 220193379, Fax: +82 234625994, e-mail: jsjjoon@yuhs.ac

Key Words: Bile duct cancer, chemotherapy, immune function, Korean Red ginseng, pancreatic cancer. chemotherapy, showed higher levels of $C D 4^{+} T$ lymphocytes and $\mathrm{CD}^{+} / \mathrm{CD}^{+} \mathrm{T}$ lymphocyte ratio after chemotherapy.

One of the strategies employed by cancer cells to develop treatment resistance is to suppress cellular antitumor immunity. Recent studies have shown that naturally occurring or tumor-induced regulatory $\mathrm{T}$ cells and immature myeloid cells including myeloid-derived suppressor cells down-regulate immune surveillance and antitumor immunity and create an immunosuppressive environment in the host (1-4). Therefore, to achieve a potent antitumor effect, such immunosuppressive factors need to be overcome.

Natural compounds derived from plants, such as ginsenosides, have been gaining interest as promising candidates for development as anticancer agents owing to their low toxicity and antiangiogenic properties. Korean Red ginseng is derived from Panax ginseng Meyer by steaming and is one of the most widely used medicinal herbs in Asia and North America (5). It is composed of saponins including ginsenosides and polysaccharides (6-8). Ginsenosides are known to have beneficial effects on cardiovascular and immune functions in addition to possible chemoprotective and therapeutic effects in vitro and in vivo (9-11). Korean Red ginseng is also known to enhance $\mathrm{T}$ cell proliferation and cytokine secretion by inhibiting the immunosuppressive activity of myeloid-derived suppressor cells (12). Given this background, our study aimed at clarifying the effect of Korean Red ginseng administered with adjuvant chemotherapy on immune function in patients with bile duct or pancreatic cancer.

\section{Patients and Methods}

Study design. This was a prospective, randomized controlled trial performed at a single tertiary hospital from January 2012 to January 2016. The trial was approved by the institutional review board of Gangnam Severance Hospital, Yonsei University College of Medicine, Korea (3-2011-0233). Written informed consent was 


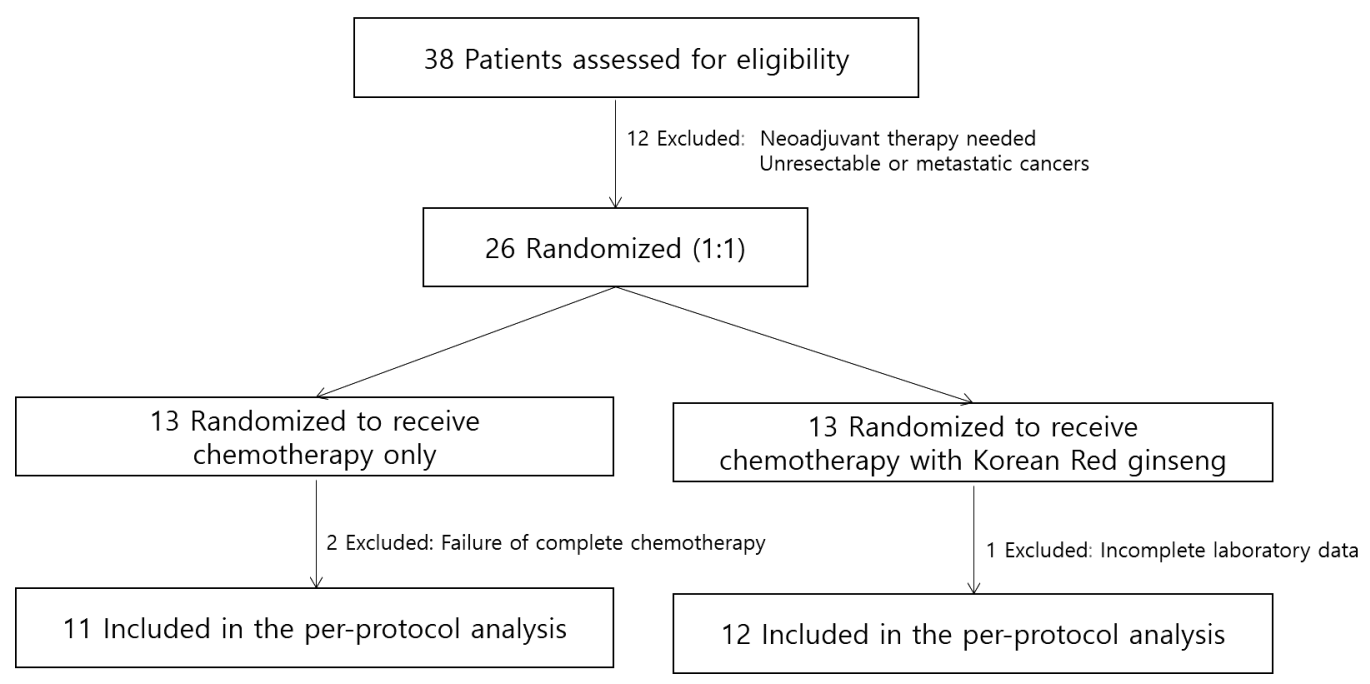

Figure 1. Flow diagram of patient enrollment. Three patients were excluded from the data analysis due to failure to maintain chemotherapy or incomplete laboratory data.

obtained from all participants. In all, 26 consecutive patients who underwent curative resection for bile duct or pancreatic cancer followed by adjuvant chemotherapy were included. The enrolled patients were categorized into the ginseng or control groups in a 1:1 ratio (Figure 1). Patients were excluded from the trial under specific conditions: 1) preoperative chemotherapy or radiotherapy, 2) palliative resection, 3) failure to take the Korean Red ginseng, 4) failure to visit regularly after operation.

Intervention. A regimen comprising 5-fluorouracil/leucovorin or gemcitabine alone was used as adjuvant chemotherapy for bile duct or pancreatic cancer. Folinic acid $\left(20 \mathrm{mg} / \mathrm{m}^{2}\right)$ was administered as an intravenous bolus followed by an intravenous bolus of fluorouracil $\left(425 \mathrm{mg} / \mathrm{m}^{2}\right)$ on 3 consecutive days every 21 days. Gemcitabine $(1,000$ $\mathrm{mg} / \mathrm{m}^{2}$ ) was infused over 30 min once a week for 3 out of 4 weeks. Each regimen was administered to the patients for 6 cycles.

The ginseng group received $3 \mathrm{~g}$ of Korean Red ginseng (Korea Ginseng Corporation, Seoul, Republic of Korea) daily as a pill. The dosage of $3 \mathrm{~g} /$ day was decided based on the safety dose from previous reports $(13,14)$. Peripheral blood sampling was performed thrice during the study period: before the initiation of adjuvant chemotherapy, during chemotherapy, and after the end of chemotherapy (Figure 2). Immune-related markers including CD4+ T lymphocytes; CD8 ${ }^{+}$T lymphocytes; immunoglobulins $\mathrm{G}, \mathrm{A}$, and $\mathrm{M}$; absolute neutrophil count; and total lymphocyte count were evaluated. To assess the toxic effects of Korean Red ginseng, the prevalence of adverse events was investigated using the Common Terminology Criteria for Adverse Events v4.0.

Statistical analysis. The target sample size was calculated to have $80 \%$ power with a type I error rate of 0.05 and a dropout rate of $10 \%$. Incremental differences between the two groups were based on a previous study, reporting 1.5 fold higher levels of antiinflammatory cytokines in the ginseng group in colorectal cancer (13). All analyses were conducted in the per-protocol population. Statistical analyses were performed using SPSS software, version
21.0 (SPSS Inc., Chicago, IL, USA). Categorical variables were analyzed using Chi-square tests or Fisher's exact tests, and continuous variables were analyzed using Student's $t$-tests. A $p$-value of $<0.05$ was considered statistically significant.

\section{Results}

Patient demographics. Baseline characteristics of the enrolled patients are listed in Table I. Intergroup differences regarding sex, age, body surface area, location of cancer, and intravenous chemotherapy regimen were not significant.

Immune and inflammatory parameters in peripheral blood samples. Comparison of immune-related parameters revealed no difference between the two groups before and during the period of adjuvant chemotherapy. However, after chemotherapy, the percentage of $\mathrm{CD}^{+} \mathrm{T}$ lymphocytes was higher in the ginseng group (ginseng $v s$. control $=42.0 \% v s$. $33.7 \%, p=0.048$ ) (Table II). Further, the ratio of $\mathrm{CD}^{+} / \mathrm{CD}^{+}$ $\mathrm{T}$ lymphocytes was not significantly different before and after chemotherapy between the groups. Nevertheless, the ratio of $\mathrm{CD} 4^{+} / \mathrm{CD}^{+} \mathrm{T}$ lymphocytes showed an increasing trend and a decline after chemotherapy in the ginseng and control groups, respectively. Moreover, after chemotherapy, the ratio of $\mathrm{CD}^{+} / \mathrm{CD}^{+} \mathrm{T}$ lymphocytes was higher in the ginseng group (ginseng vs. control=2.0 vs. 1.3, $p=0.027$ ) (Figure 3).

Adverse events during adjuvant chemotherapy. To evaluate the toxicity of ginseng administered during adjuvant chemotherapy, the prevalence of adverse events during chemotherapy was determined. The number of patients with neutropenia of a grade higher than 3 , granulocyte colony- 


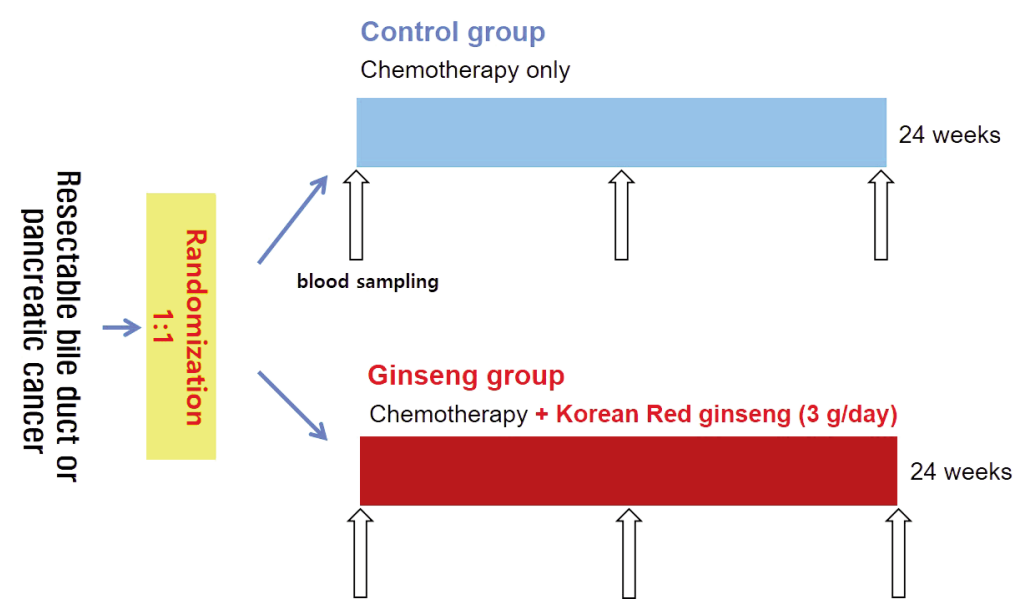

Figure 2. Study scheme.

Table I. Patient demographics.

\begin{tabular}{lccc}
\hline & $\begin{array}{c}\text { Ginseng group } \\
\text { n (\%) }\end{array}$ & $\begin{array}{c}\text { Control group } \\
\text { n (\%) }\end{array}$ & $p$-Value \\
\hline $\begin{array}{l}\text { Gender } \\
\text { Male }\end{array}$ & $8(61.5)$ & $8(61.5)$ & 1.000 \\
$\quad \begin{array}{l}\text { Female } \\
\text { Age (years) }\end{array}$ & $5(38.5)$ & $5(38.5)$ & \\
$\quad$ Mean (SD) & $62.2(11.2)$ & $62.8(9.2)$ & 0.880 \\
$\begin{array}{l}\text { BSA (kg/m }) \\
\text { Mean (SD) }\end{array}$ & $1.70(0.19)$ & $1.67(0.21)$ & 0.650 \\
$\begin{array}{l}\text { Location of cancer } \\
\text { Pancreas }\end{array}$ & $7(53.8)$ & $6(46.2)$ & 1.000 \\
$\quad$ Bile duct & $6(46.2)$ & $7(53.8)$ & \\
Chemotherapy regimen & & & \\
$\quad$ Gemcitabine & $10(76.9)$ & $8(61.5)$ & 0.673 \\
FL chemotherapy & $3(23.1)$ & $5(38.5)$ & \\
\hline
\end{tabular}

BSA: Body surface area; FL: 5-fluorouracil/leucovorin.

stimulating factor use, or elevations in aspartate aminotransferase or alanine aminotransferase of a grade higher than 3 were not different between the two groups. Moreover, no difference in the number of neutropenic episodes or granulocyte colony-stimulating factor injections was observed between the two groups (Table III).

\section{Discussion}

In this study, we aimed to determine the clinical effect of Korean Red ginseng as an immune-modulating agent in patients undergoing adjuvant chemotherapy for bile duct or

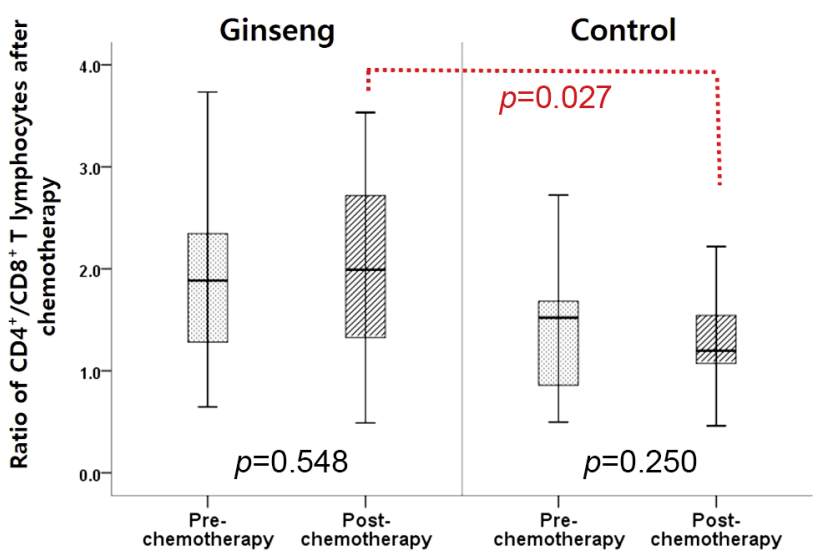

Figure 3. Comparison of the ratio of $\mathrm{CD}^{+} / \mathrm{CD} 8^{+} \mathrm{T}$ lymphocytes between the two groups. This figure shows the ratio of $C D 4^{+} / C D 8^{+} T$ lymphocytes before and after chemotherapy in the two groups. The Ginseng group had a significantly higher ratio of $\mathrm{CD}^{+} / \mathrm{CD}^{+} \mathrm{T}$ lymphocytes after chemotherapy compared to the control group.

pancreatic cancer. Compared to the control group, the ginseng group showed a higher percentage of $\mathrm{CD}^{+} \mathrm{T}$ lymphocytes after chemotherapy. Furthermore, the ratio of $\mathrm{CD}^{+} / \mathrm{CD}^{+} \mathrm{T}$ lymphocytes after chemotherapy was higher in the ginseng group.

Genetic or epigenetic disarrangements because of inflammation are known to cause angiogenesis, metastasis, and remodeling to malignant features, which leads to cancer progression (15-17). Korean Red ginseng is heat-processed ginseng prepared by the repeated processes of steaming and drying of fresh ginseng (18). It has been known to undergo changes in its types and concentrations of chemical 
Table II. Comparison of immune-related parameters between the two groups.

\begin{tabular}{|c|c|c|c|}
\hline & $\begin{array}{c}\text { Ginseng group }(\mathrm{n}=12) \\
\quad(\text { mean, } \mathrm{SD})\end{array}$ & $\begin{array}{l}\text { Control group }(\mathrm{n}=11) \\
\quad(\text { mean, } \mathrm{SD})\end{array}$ & $p$-Value \\
\hline \multicolumn{4}{|l|}{ Before chemotherapy } \\
\hline Absolute neutrophil count $\left(10^{3} / \mu \mathrm{l}\right)$ & $3.5(1.4)$ & $3.0(1.8)$ & 0.445 \\
\hline C-reactive protein (mg/l) & $5.5(11.6)$ & $5.2(7.7)$ & 0.939 \\
\hline Total lymphocyte count $\left(10^{3} / \mu 1\right)$ & $2.1(0.5)$ & $1.0(0.6)$ & 0.625 \\
\hline AST (IU/l) & $24.8(8.0)$ & $33.8(22.2)$ & 0.185 \\
\hline ALT (IU/1) & $20.2(15.2)$ & $31.2(25.1)$ & 0.186 \\
\hline $\operatorname{IgG}(\mathrm{mg} / \mathrm{dl})$ & $1,274.9(254.6)$ & $1,396.9(459.3)$ & 0.370 \\
\hline $\operatorname{IgA}(\mathrm{mg} / \mathrm{dl})$ & $246.0(56.2)$ & $264.9(88.3)$ & 0.521 \\
\hline $\operatorname{IgM}(\mathrm{mg} / \mathrm{dl})$ & $113.4(71.9)$ & $96.1(45.3)$ & 0.471 \\
\hline $\mathrm{CD} 4^{+} \mathrm{T}$ lymphocytes $(\%)$ & $43.0(7.9)$ & $36.1(11.6)$ & 0.125 \\
\hline $\mathrm{CD} 8+\mathrm{T}$ lymphocytes $(\%)$ & $25.9(8.4)$ & $28.8(12.4)$ & 0.509 \\
\hline $\mathrm{CD}^{+} / \mathrm{CD} 8^{+} \mathrm{T}$ lymphocyte ratio & $1.9(0.9)$ & $1.5(0.8)$ & 0.225 \\
\hline \multicolumn{4}{|l|}{ During chemotherapy } \\
\hline Absolute neutrophil count $\left(10^{3} / \mu \mathrm{l}\right)$ & $3.1(1.8)$ & $3.0(1.0)$ & 0.822 \\
\hline C-reactive protein $(\mathrm{mg} / \mathrm{l})$ & $1.3(1.5)$ & $2.6(3.7)$ & 0.318 \\
\hline Total lymphocyte count $\left(10^{3} / \mu \mathrm{l}\right)$ & $2.0(0.6)$ & $1.8(0.6)$ & 0.723 \\
\hline AST (IU/l) & $26.9(10.5)$ & $28.6(15.1)$ & 0.743 \\
\hline ALT (IU/l) & $23.6(18.6)$ & $29.5(23.6)$ & 0.490 \\
\hline $\operatorname{IgG}(\mathrm{mg} / \mathrm{dl})$ & $1,289.0(217.3)$ & $1,362.8(210.9)$ & 0.388 \\
\hline $\operatorname{IgA}(\mathrm{mg} / \mathrm{dl})$ & $250.0(66.4)$ & $246.6(61.0)$ & 0.891 \\
\hline $\operatorname{IgM}(\mathrm{mg} / \mathrm{dl})$ & $120.4(65.3)$ & $89.1(42.6)$ & 0.161 \\
\hline $\mathrm{CD} 4+\mathrm{T}$ lymphocytes $(\%)$ & $40.9(8.2)$ & $34.6(8.8)$ & 0.090 \\
\hline CD8+ $\mathrm{T}$ lymphocytes (\%) & $25.8(9.5)$ & $28.9(8.9)$ & 0.433 \\
\hline $\mathrm{CD} 4^{+} / \mathrm{CD} 8^{+} \mathrm{T}$ lymphocyte ratio & $1.8(0.8)$ & $1.3(0.6)$ & 0.101 \\
\hline \multicolumn{4}{|l|}{ After chemotherapy } \\
\hline Absolute neutrophil count $\left(10^{3} / \mu \mathrm{l}\right)$ & $3.9(1.2)$ & $3.6(1.7)$ & 0.670 \\
\hline C-reactive protein $(\mathrm{mg} / \mathrm{l})$ & $3.1(5.9)$ & $5.9(10.2)$ & 0.432 \\
\hline Total lymphocyte count $\left(10^{3} / \mu \mathrm{l}\right)$ & $2.0(0.6)$ & $1.8(0.6)$ & 0.828 \\
\hline AST (IU/l) & $29.1(12)$. & $29.2(11.5)$ & 0.987 \\
\hline ALT (IU/1) & $25.3(18.7)$ & $28.8(16.6)$ & 0.622 \\
\hline $\operatorname{IgG}(\mathrm{mg} / \mathrm{dl})$ & $1,222.3(221.6)$ & $1,334.9(221.4)$ & 0.217 \\
\hline $\operatorname{IgA}(\mathrm{mg} / \mathrm{dl})$ & $293.4(100.7)$ & $342.0(120.9)$ & 0.446 \\
\hline $\operatorname{IgM}(\mathrm{mg} / \mathrm{dl})$ & $263.4(58.1)$ & $245.3(58.3)$ & 0.333 \\
\hline $\mathrm{CD}^{+}+\mathrm{T}$ lymphocytes $(\%)$ & $42.0(9.6)$ & $33.7(9.4)$ & 0.048 \\
\hline $\mathrm{CD}^{+} \mathrm{T}$ lymphocytes $(\%)$ & $24.1(9.0)$ & $29.3(11.3)$ & 0.233 \\
\hline $\mathrm{CD}^{+} / \mathrm{CD}^{+} \mathrm{T}$ lymphocyte ratio & $2.0(0.9)$ & $1.3(0.5)$ & $\mathbf{0 . 0 2 7}$ \\
\hline
\end{tabular}

AST: Aspartate aminotransferase; ALT: alanine aminotransferase; Ig: immunoglobulin. Significant $p$-Values are shown in bold.

constituents such as ginsenosides during the steaming process (19). Many researchers have attempted to identify the clinical benefits of Korean Red ginseng in terms of antitumor activity, neuroprotective effect, and management of immune system and cardiovascular disorders (20-23). Korean Red ginseng has been reported to have immunemodulating properties, whereby it could enhance T-cell proliferation, suggesting it can regulate cellular immune responses $(24,25)$.

A dynamic balance in the $\mathrm{CD} 4^{+} / \mathrm{CD}^{+}$ratio is crucial for maintaining stable immune function $(26) . \mathrm{CD}^{+} \mathrm{T}$ cells play a central role in the cellular immune response of the host and are divided into $\mathrm{CD}^{+}$helper $\mathrm{T}$ cells and $\mathrm{CD} 8^{+}$cytotoxic $\mathrm{T}$ cells. These cells boost immune responses via the secretion of lymphatic factors by $\mathrm{CD}^{+}{ }^{+}$helper $\mathrm{T}$ cells and induce other lymphatic cells crucial for an antitumor effect. Therefore, a decrease in the number of $\mathrm{CD}^{+}{ }^{+} \mathrm{T}$ cells is associated with a weakened immune function, whereas a decrease in the number of $\mathrm{CD}^{+}$cytotoxic $\mathrm{T}$ cells, which inhibit $\mathrm{CD}^{+}$and $\mathrm{B}$ cell function, enhances antibody formation and cellular immune responses (27).

A decreased $\mathrm{CD}^{+} / \mathrm{CD}^{+}$ratio has been reported to be correlated with decreased immune function $(28,29)$. Wang et al. showed that patients with non-small cell lung cancer had a significantly lower $\mathrm{CD} 4^{+} / \mathrm{CD}^{+}$ratio than healthy controls and patients with advanced-stage cancer had a significantly lower $\mathrm{CD}^{+} / \mathrm{CD}^{+}$ratio than those with earlystage cancer (27). In the present study, the ginseng group 
Table III. Prevalence of chemotherapy-related adverse events.

\begin{tabular}{lccc}
\hline & $\begin{array}{c}\text { Ginseng group } \\
\text { n (\%) }\end{array}$ & $\begin{array}{c}\text { Control group } \\
\text { n (\%) }\end{array}$ & $p$-Value \\
\hline No. of patents with neutropenia of grade $\geq 3^{\dagger}$ & $5(41.6)$ & $3(27.2)$ & 0.453 \\
No. of episodes of neutropenia of grade $\geq 3^{\dagger}$ & $1(0-9)$ & $0(0-3)$ & $3(27.2)$ \\
No. of patients with G-CSF use & $4(33.3)$ & $0(0-2)$ & $0.210^{*}$ \\
No. of episodes with injection of G-CSF & $1(0-6)$ & $0(0)$ & $0.092^{*}$ \\
No. of patients with elevated AST or ALT of grade $\geq 3^{\dagger}$ & $0(0)$ & NS \\
\hline
\end{tabular}

No.: Numbers; G-CSF: granulocyte colony-stimulating factor; AST: aspartate aminotransferase; ALT: alanine aminotransferase; *Mann-Whitney $U$-test; ${ }^{\dagger}$ grades according to the CTCAE.

showed a significantly higher number of $\mathrm{CD}^{+} \mathrm{T}$ lymphocytes after chemotherapy along with a higher ratio of $\mathrm{CD}^{+} / \mathrm{CD}^{+} \mathrm{T}$ lymphocytes. This finding demonstrates that Korean Red ginseng may have an immune-modulating effect and could be beneficial for patients who underwent cytotoxic chemotherapy.

Although this was a prospective trial, the data obtained are preliminary and should be interpreted very carefully due to the small number of patients enrolled and the relatively heterogeneous baseline characteristics of the sample. Nevertheless, to our knowledge, this is the first randomized clinical trial investigating the effects of Korean Red ginseng in real-world hepatobiliary or pancreatic cancer patients undergoing adjuvant chemotherapy. We found that simultaneous administration of Korean Red ginseng with adjuvant chemotherapy resulted in a higher number of $\mathrm{CD} 4^{+}$ lymphocytes as well as a higher ratio of $\mathrm{CD} 4^{+} / \mathrm{CD}^{+} \mathrm{T}$ lymphocytes after chemotherapy in patients with bile duct or pancreatic cancer. Thus, the findings of this study are noteworthy and suggest that Korean Red ginseng is a safe alternative immune-modulating agent for use during chemotherapy in patients with bile duct or pancreatic cancer.

\section{Conflicts of Interest}

The Authors have no conflicts of interest in relation to this study.

\section{Authors' Contributions}

Research design: Lee KY, Park JS and Jeong J; Statistical analysis: Kim I-k; Article writing: Kim I-k; Supervision: Kang J; Review and revision: Lee KY, Park JS and Jeong J.

\section{Acknowledgements}

This study was supported by a research grant from the Korea Ginseng Corporation. The funder was not involved in the study design, data management, draft preparation, or decision to publish. The abstract was presented as a poster at the American Society for Parenteral and Enteral Nutrition (ASPEN) Nutrition Science and Practice Conference, Las Vegas, Nevada, United States of America, in January 2018.

\section{References}

1 Ostrand-Rosenberg S and Sinha P: Myeloid-derived suppressor cells: Linking inflammation and cancer. J Immunol 182(8): 44994506, 2009. PMID: 19342621. DOI: 10.4049/jimmunol.0802740

2 Marx J: Cancer immunology. Cancer's bulwark against immune attack: MDS cells. Science 319(5860): 154-156, 2008. PMID: 18187637. DOI: $10.1126 /$ science. 319.5860 .154

3 Diaz-Montero CM, Salem ML, Nishimura MI, Garrett-Mayer E, Cole DJ and Montero AJ: Increased circulating myeloid-derived suppressor cells correlate with clinical cancer stage, metastatic tumor burden, and doxorubicin-cyclophosphamide chemotherapy. Cancer Immunol Immunother 58(1): 49-59, 2009. PMID: 18446337. DOI: $10.1007 /$ s00262-008-0523-4

4 Almand B, Clark JI, Nikitina E, van Beynen J, English NR, Knight SC, Carbone DP and Gabrilovich DI: Increased production of immature myeloid cells in cancer patients: A mechanism of immunosuppression in cancer. J Immunol 166(1): 678-689, 2001. PMID: 11123353. DOI: 10.4049/jimmunol.166.1.678

5 Ahuja A, Kim JH, Kim JH, Yi YS and Cho JY: Functional role of ginseng-derived compounds in cancer. J Ginseng Res 42(3): 248254, 2018. PMID: 29983605. DOI: 10.1016/j.jgr.2017.04.009

6 Lee SM, Bae BS, Park HW, Ahn NG, Cho BG, Cho YL and Kwak YS: Characterization of Korean Red Ginseng (Panax ginseng Meyer): History, preparation method, and chemical composition. J Ginseng Res 39(4): 384-391, 2015. PMID: 26869832. DOI: $10.1016 /$ j.jgr.2015.04.009

7 Christensen LP: Ginsenosides chemistry, biosynthesis, analysis, and potential health effects. Adv Food Nutr Res 55: 1-99, 2009. PMID: 18772102. DOI: 10.1016/S1043-4526(08)00401-4

8 Shin BK, Kwon SW and Park JH: Chemical diversity of ginseng saponins from Panax ginseng. J Ginseng Res 39(4): 287-298, 2015. PMID: 26869820. DOI: 10.1016/j.jgr.2014.12.005

9 Karmazyn M, Moey M and Gan XT: Therapeutic potential of ginseng in the management of cardiovascular disorders. Drugs 71(15): 1989-2008, 2011. PMID: 21985167. DOI: 10.2165/115 94300-000000000-00000

10 Liu J, Wang S, Liu H, Yang L and Nan G: Stimulatory effect of saponin from Panax ginseng on immune function of lymphocytes in the elderly. Mech Ageing Dev 83(1): 43-53, 1995. PMID: 8523901. DOI: 10.1016/0047-6374(95)01618-a

11 Shin HR, Kim JY, Yun TK, Morgan G and Vainio H: The cancerpreventive potential of Panax ginseng: A review of human and experimental evidence. Cancer Causes Control 11(6): 565-576, 2000. PMID: 10880039. DOI: 10.1023/a:1008980200583 
12 Jeon C, Kang S, Park S, Lim K, Hwang KW and Min H: T cell stimulatory effects of korean red ginseng through modulation of myeloid-derived suppressor cells. J Ginseng Res 35(4): 462-470, 2011. PMID: 23717093. DOI: 10.5142/jgr.2011.35.4.462

13 Boo Y-J, Park J-M, Kim J and Suh S-O: Prospective study for Korean red ginseng extract as an immune modulator following a curative surgery in patients with advanced colon cancer. J Ginseng Res 31(1): 54-59, 2007. DOI: 10.5142/JGR.2007.31.1.054

14 Suh S-O, Kim J and Cho M-Y: Prospective study for Korean red ginseng extract as an immune modulator following a curative gastric resection in patients with advanced gastric cancer. J Ginseng Res 28(2): 104-110, 2004. DOI: 10.5142/jgr.2004.28.2.104

15 Coussens LM, Zitvogel L and Palucka AK: Neutralizing tumorpromoting chronic inflammation: a magic bullet? Science 339(6117): 286-291, 2013. PMID: 23329041. DOI: 10.1126/science.1232227

16 Demaria S, Pikarsky E, Karin M, Coussens LM, Chen YC, ElOmar EM, Trinchieri G, Dubinett SM, Mao JT, Szabo E, Krieg A, Weiner GJ, Fox BA, Coukos G, Wang E, Abraham RT, Carbone M and Lotze MT: Cancer and inflammation: Promise for biologic therapy. J Immunother 33(4): 335-351, 2010. PMID: 20386472. DOI: 10.1097/CJI.0b013e3181d32e 74

17 Lu H, Ouyang W and Huang C: Inflammation, a key event in cancer development. Mol Cancer Res 4(4): 221-233, 2006. PMID: 16603636. DOI: 10.1158/1541-7786.MCR-05-0261

18 Hyun SH, Kim SW, Seo HW, Youn SH, Kyung JS, Lee YY, In G, Park CK and Han CK: Physiological and pharmacological features of the non-saponin components in Korean red ginseng. J Ginseng Res 44(4): 527-537, 2020. PMID: 32617032. DOI: 10.1016/j.jgr.2020.01.005

19 Kim WY, Kim JM, Han SB, Lee SK, Kim ND, Park MK, Kim $\mathrm{CK}$ and Park JH: Steaming of ginseng at high temperature enhances biological activity. J Nat Prod 63(12): 1702-1704, 2000. PMID: 11141123. DOI: 10.1021/np990152b

20 Helms S: Cancer prevention and therapeutics: Panax ginseng. Altern Med Rev 9(3): 259-274, 2004. PMID: 15387718.

21 Cho SK, Kim D, Yoo D, Jang EJ, Jun JB and Sung YK: Korean Red ginseng exhibits no significant adverse effect on disease activity in patients with rheumatoid arthritis: A randomized, double-blind, crossover study. J Ginseng Res 42(2): 144-148, 2018. PMID: 29719460. DOI: 10.1016/j.jgr.2017.01.006

22 Vuksan V, Sievenpipper J, Jovanovski E and Jenkins A: Current clinical evidence for korean red ginseng in management of diabetes and vascular disease: A Toronto's ginseng clinical testing program. Journal of Ginseng Research 34(4): 264-273, 2019. DOI: 10.5142 /jgr.2010.34.4.264
$23 \mathrm{Kim}$ S, Lee Y and Cho J: Korean red ginseng extract exhibits neuroprotective effects through inhibition of apoptotic cell death. Biol Pharm Bull 37(6): 938-946, 2014. PMID: 24882407. DOI: 10.1248/bpb.b13-00880

24 Kang S and Min H: Ginseng, the 'immunity boost': The effects of Panax ginseng on immune system. J Ginseng Res 36(4): 354368, 2012. PMID: 23717137. DOI: 10.5142/jgr.2012.36.4.354

25 Hwang I, Ahn G, Park E, Ha D, Song JY and Jee Y: An acidic polysaccharide of Panax ginseng ameliorates experimental autoimmune encephalomyelitis and induces regulatory $\mathrm{T}$ cells. Immunol Lett 138(2): 169-178, 2011. PMID: 21524666. DOI: 10.1016/j.imlet.2011.04.005

26 Dou X, Wang RB, Yan HJ, Jiang SM, Meng XJ, Zhu KL, Xu $\mathrm{XQ}$ and $\mathrm{Mu} \mathrm{DB}$ : Circulating lymphocytes as predictors of sensitivity to preoperative chemoradiotherapy in rectal cancer cases. Asian Pac J Cancer Prev 14(6): 3881-3885, 2013. PMID: 23886201. DOI: 10.7314/apjcp.2013.14.6.3881

27 Wang WJ, Tao Z, Gu W and Sun LH: Variation of blood T lymphocyte subgroups in patients with non- small cell lung cancer. Asian Pac J Cancer Prev 14(8): 4671-4673, 2013. PMID: 24083723. DOI: 10.7314/apjcp.2013.14.8.4671

28 Erdem MG, Cinkilic N, Vatan O, Yilmaz D, Bagdas D and Bilaloglu R: Genotoxic and anti-genotoxic effects of vanillic acid against mitomycin $\mathrm{C}$-induced genomic damage in human lymphocytes in vitro. Asian Pac J Cancer Prev 13(10): 4993-4998, 2012. PMID: 23244097. DOI: 10.7314/apjcp.2012.13.10.4993

29 Nugroho AE, Hermawan A, Nastiti K, Suven, Elisa P, Hadibarata $\mathrm{T}$ and Meiyanto E: Immunomodulatory effects of hexane insoluble fraction of Ficus septica Burm. F. in doxorubicin-treated rats. Asian Pac J Cancer Prev 13(11): 5785-5790, 2012. PMID: 23317257. DOI: 10.7314/apjcp.2012.13.11.5785
Received March 4, 2021

Revised March 30, 2021 Accepted March 31, 2021 